Background: Colorectal cancer is an important health problem in Poland as well as around the whole world. Radical or palliative treatment often requires making an artificial stoma in many patients.

Aim of the study: To assess physical rehabilitation and psycho-sexual prob lems of patients with rectum cancer and stoma.

Material and methods: 50 patients with stoma who had undergone surgery because of rectal cancer participated in this survey. The survey was performed in the Oncology Centre in Bydgoszcz in 2008. The questionnaire contains questions related to socio-demographic information, self-assessment about used physical rehabilitation and psychosexual feelings.

Results: $28 \%, 34 \%$ and $28 \%$ of patients know the goals of rehabilitation before surgery and during the early and late period after surgery, respectively. Information regarding psychological and sexual help was given to $12(24 \%)$ and $3(6 \%)$ patients, respectively. Basic physical activity before surgery was declared by 30 patients $(60 \%)$, physical activity was not changed in 22 (44\%) after surgery. Changes in intimate life after colostomy under cessation of sexual relations were observed in 18 patients (36\%). As many as 46 patients (92\%) did not use any assistance from a psychologist or sexologist.

Conclusions: In the peri-operative period physical rehabilitation as part of treatment of patients with colorectal cancer and stoma was not sufficient. Only a few patients used psycho-sexual rehabilitation; it was the most neglected element of rehabilitative treatment. Patients with the most severe disease feel resigned to their fate, fear of death as well as happiness that they can be alive.

Key words: rectal cancer, stoma, rehabilitation, psycho-sexual problems.

\section{The assessment of rehabilitation and psycho-sexual problems in patients who suffered from rectal cancer with stomas}

\author{
Andrzej Nowicki ${ }^{1}$, Olimpia Kula ${ }^{2}$, Zbigniew Kula ${ }^{3}$, Katarzyna Rzepka ${ }^{1}$, \\ Wojciech Zegarski ${ }^{3,4}$
}

\begin{abstract}
1Department of Oncological Nursing, Ludwik Rydygier Collegium Medicum, Bydgoszcz, Nicolaus Copernicus University, Toruń

${ }^{2}$ Rehabilitation Centre for Adults, Charleville, France

3 Department of Endoscopy, Oncology Centre - Prof. Lukaszczyk Memorial Hospital, Bydgoszcz

4Department and Clinic of Oncological Surgery, Ludwik Rydygier Collegium Medicum, Bydgoszcz, Nicolaus Copernicus University, Toruń
\end{abstract}

The colorectal carcinoma incidence rate grows with patient's age. Poland belongs to a group of countries with moderate rates of morbidity and mortality. The recovery rate for colorectal carcinoma is significantly higher in recent years because of improving early detection of this carcinoma [1].

Surgery for creation of an "abdominal anus" are made because of rectal carcinoma most frequently. There are about 20000 patients with stomas in our country; the frequency of this type of surgery is constantly growing. About 4500 new stomas are created each year [2].

Physical fitness has great importance for successful rehabilitation of patients with stomas. It depends on various factors such as age, gender, general health condition, current complaints, endurance, general fitness and past diseases among others. Rehabilitation may be divided into the early preoperative, early postoperative and late postoperative periods [3-5]. Patient education has essential importance before surgery mainly. It has been shown that patients with a higher knowledge level and powerful motivation do exercises more readily [4]. It is justified to convince patients about the necessity of increasing motor activity and its benefits for the treatment process. [6].

Apart from a correctly performed surgical procedure, providing the patient with appropriate stoma devices and teaching him/her about hygienic and care procedures also belong to broadly defined rehabilitation [4, 7, 8]. Appropriate education of the patient's family and close relatives also has great importance [9]. Depending on the patient's personality, the physician's approach should be individual in its character. Establishment of emotional communication is an important element. It sometimes may be difficult to do and conversation alone is not sufficient; then it is necessary to use help from a psychologist.

Sexual rehabilitation issues are an inherent part of the rehabilitation process of patients after surgery for rectal carcinoma. Past treatment, age, gender, general and psychological conditions, and current partnerships are among the factors that influence the sexual domain. The patient loses confidence in sexual attractiveness, which is lowered because of stoma creation. The members of the rehabilitation team should offer discussion about sexual issues. It is necessary to remember that it is a subtle issue and using help from professionals is crucial $[6,10,11]$.

Assessment of the quality of appropriate patient arrangement through complex work of the rehabilitation team may improve the process of physical, psychological and sexual fitness restoration and therefore contribute to improving his/her relationships with family and society. 


\section{Objectives}

Self-assessment of physical rehabilitation and psychosexual problems in patients with rectal carcinoma and stoma was the main objective of this work.

\section{Material and methods}

Fifty patients with stomas who had undergone surgery for rectal carcinoma were included in our research. The questionnaire survey was performed in the Prof. Franciszek Lukaszczyk Oncology Centre in Bydgoszcz in 2008. There were 20 women and 30 men aged from 44 to 72 years (mean age 58.6). A permanent stoma was created in 39 patients (78\%) and a temporary stoma in the remaining 11 patients (22\%). All patients underwent combined treatment procedures.

The original questionnaire form included 24 closed questions with a set of answers for choosing one of them by the patient. The questions were related to social-demographic data, patients' assessment of physical rehabilitation and their feelings about the psycho-sexual domain. Patients after surgery selected their intensity of feelings using a 5-point scale, where 1 means the lowest and 5 the highest intensity.

The survey was started after permission from the Bioethical Committee of Collegium Medicum in Bydgoszcz, Nicolaus Copernicus University in Torun was obtained. Statisti- cal analysis was performed using Microsoft Excel and its functions. Tables and figures presented here show numerical and percentage values. The value of the level of significance was set at $p<0.05$.

\section{Results}

\section{Social-demographic data}

The largest group includes patients with secondary education level, living in big cities with their families, professionally active. Only 3 (6\%) patients were still professionally active after surgery. Above half of patients before and after surgery stated that their economic condition was good (Table 1).

\section{Patients' knowledge about rehabilitation}

Appropriateness of rehabilitation was known by 14 (28\%), 17 (34\%) and 14 (28\%) patients before surgery, and in the early and late postoperative period, respectively. The rest of patients did not understand the appropriateness of such conduct. Information about breathing and anti-thrombosis exercises as well as coughing up was delivered to persons who understood the appropriateness of rehabilitation. In the late postoperative period information about exercises

Table 1. Social-demographic data

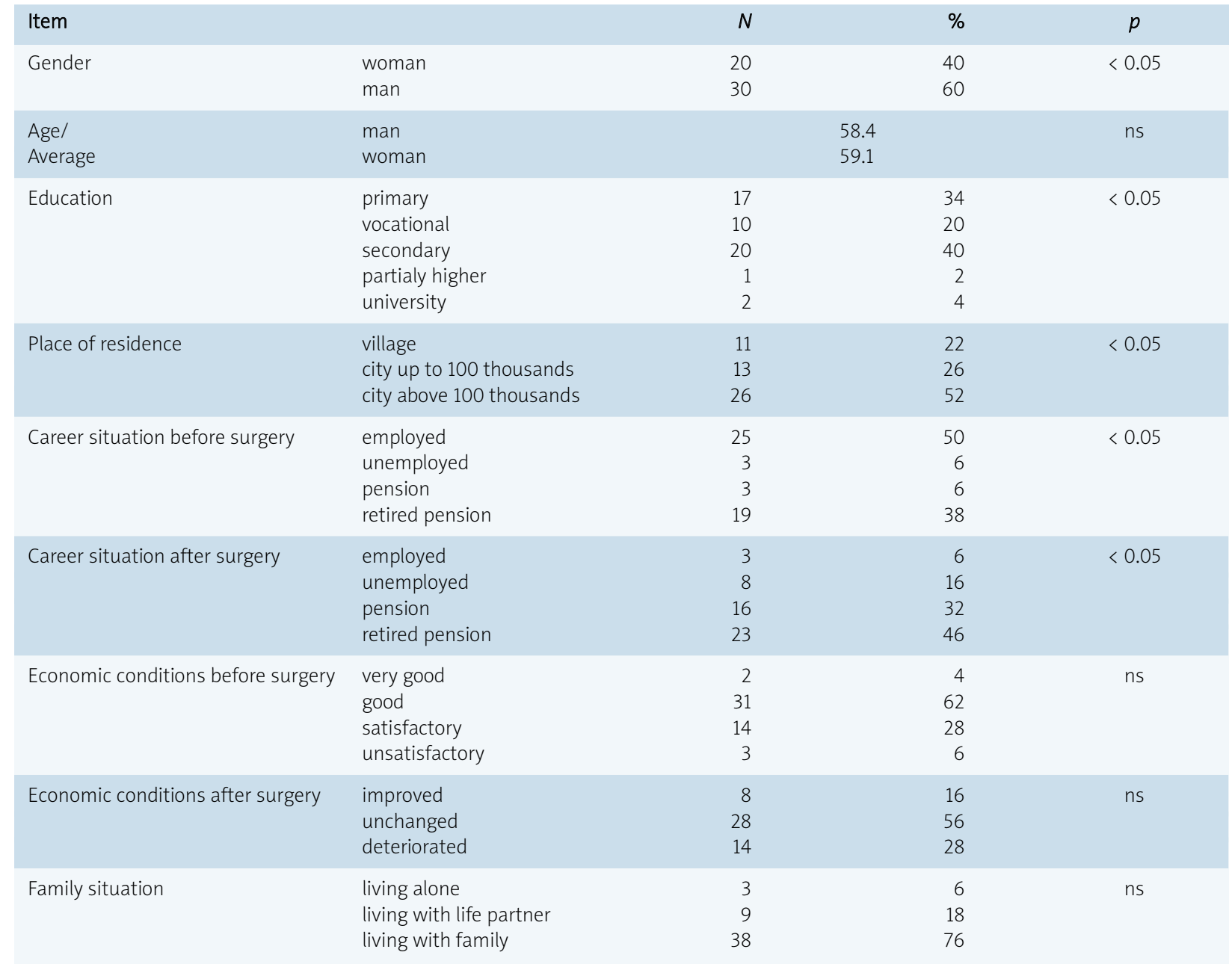


that strengthened abdominal press and improving physical activity was given. Additionally, patients were informed about stoma care procedures. Regarding psychological and sexual help, information was given to $12(24 \%)$ and $3(6 \%)$ patients, respectively (Table 2).

\section{Self-assessment of physical rehabilitation}

Basic physical activity before surgery was declared by 30 patients (60\%), and it was unchanged in 22 (44\%) patients in the postoperative period. 20 (40\%) patients did not pay attention to physical activity (Table 3 ).

\section{Psycho-sexual disturbances}

Patients most frequently got support from physicians and family, 38 (76\%) and 27 (54\%), respectively. Changes in sexual life after stoma creation occurred in the form of ceasing sexual relationships in 18 patients (36\%). As many as 46 (92\%) patients did not use advice from psychologists or sex therapists.

Table 2. Knowledge and information about rehabilitation

\begin{tabular}{|c|c|c|c|c|c|c|c|c|}
\hline \multicolumn{6}{|l|}{ Item } & \multicolumn{2}{|c|}{$N$} & \multirow{2}{*}{$\begin{aligned} & p \\
< & 0.05\end{aligned}$} \\
\hline $\begin{array}{l}\text { Patients knowledge } \\
\text { about physical reha- } \\
\text { bilitation before } \\
\text { surgery }\end{array}$ & \multicolumn{5}{|c|}{$\begin{array}{l}\text { persons who got to know usefulness of rehabilitation } \\
\text { persons who got to know usefulness of rehabilitation in less understandable way } \\
\text { persons who did not hear about rehabilitation of patients with stoma }\end{array}$} & \multicolumn{2}{|c|}{$\begin{array}{r}14 \\
3 \\
33\end{array}$} & \\
\hline $\begin{array}{l}\text { Patients knowledge } \\
\text { about physical reha- } \\
\text { bilitation after surgery }\end{array}$ & \multicolumn{5}{|c|}{$\begin{array}{l}\text { persons who got to know usefulness of rehabilitation } \\
\text { persons who got to know usefulness of rehabilitation in less understandable way } \\
\text { persons who did not hear about rehabilitation of patients with stoma }\end{array}$} & \multicolumn{2}{|c|}{$\begin{array}{r}17 \\
3 \\
30\end{array}$} & $<0.05$ \\
\hline \multirow{2}{*}{$\begin{array}{l}\text { Patients knowledge } \\
\text { about physical reha- } \\
\text { bilitation in late } \\
\text { postoperative period }\end{array}$} & \multicolumn{5}{|c|}{$\begin{array}{l}\text { persons who got to know usefulness of rehabilitation } \\
\text { persons who got to know usefulness of rehabilitation in less understandable way } \\
\text { persons who did not hear about rehabilitation of patients with stoma }\end{array}$} & \multicolumn{2}{|c|}{$\begin{array}{r}14 \\
8 \\
28\end{array}$} & $<0.05$ \\
\hline & & \multicolumn{2}{|c|}{$\begin{array}{l}\text { Before } \\
\text { surgery }\end{array}$} & \multicolumn{2}{|c|}{$\begin{array}{c}\text { Early } \\
\text { postoperative }\end{array}$} & \multicolumn{2}{|c|}{$\begin{array}{c}\text { Late } \\
\text { postoperative } \\
N \quad \%\end{array}$} & \\
\hline $\begin{array}{l}\text { Range of knowledge } \\
\text { that has been given } \\
\text { persons who got to } \\
\text { know usefulness of } \\
\text { rehabilitation depen- } \\
\text { ding on duration of } \\
\text { treatment* }\end{array}$ & $\begin{array}{l}\text { breathing exercises } \\
\text { antithrombotic exercises } \\
\text { expectoration and coughing } \\
\text { thoracic path breathing } \\
\text { appropriate positions } \\
\text { exercises for strenghtening of abdominal press } \\
\text { general fitness exercises } \\
\text { general physical activity exercises }\end{array}$ & $\begin{array}{c}10 \\
12 \\
8 \\
6\end{array}$ & $\begin{array}{l}20 \\
24 \\
16 \\
12\end{array}$ & $\begin{array}{c}12 \\
12 \\
8 \\
6 \\
6 \\
16\end{array}$ & $\begin{array}{l}24 \\
24 \\
16 \\
12 \\
12 \\
32\end{array}$ & $\begin{array}{c}6 \\
12\end{array}$ & $\begin{array}{l}12 \\
24\end{array}$ & \\
\hline $\begin{array}{l}\text { Range of additional } \\
\text { knowledge that has } \\
\text { been given patients* }\end{array}$ & $\begin{array}{l}\text { skin care around stoma } \\
\text { way of stoma's bags changing } \\
\text { information about stoma clinics } \\
\text { refund of equipments } \\
\text { kind of equipments } \\
\text { information about internet forums for „stoma's } \\
\text { risk of occurence of complications concerning st } \\
\text { diet } \\
\text { phychological assistance } \\
\text { sexuologist assistance } \\
\text { availability of educational materials about stoma }\end{array}$ & $\begin{array}{l}\text { Ien } \\
\text { na }\end{array}$ & & & & $\begin{array}{r}44 \\
47 \\
16 \\
34 \\
41 \\
5 \\
8 \\
32 \\
12 \\
3 \\
47\end{array}$ & $\begin{array}{r}88 \\
94 \\
32 \\
68 \\
82 \\
10 \\
16 \\
64 \\
24 \\
6 \\
94\end{array}$ & $<0.05$ \\
\hline
\end{tabular}

${ }^{*}$ One patient received more than one information

Table 3. Self-assessment of the physical rehabilitation

\begin{tabular}{|c|c|c|c|c|}
\hline Item & & $N$ & $\%$ & $p$ \\
\hline $\begin{array}{l}\text { Physical activity } \\
\text { before surgery }\end{array}$ & $\begin{array}{l}\text { very avtive } \\
\text { basic physical activity } \\
\text { minimal physical activity }\end{array}$ & $\begin{array}{r}15 \\
30 \\
5\end{array}$ & $\begin{array}{l}30 \\
60 \\
10\end{array}$ & $<0.05$ \\
\hline $\begin{array}{l}\text { General physical } \\
\text { activity after surgery }\end{array}$ & $\begin{array}{l}\text { improved } \\
\text { unchanged } \\
\text { slightly worse } \\
\text { significantly worse }\end{array}$ & $\begin{array}{r}7 \\
22 \\
11 \\
10\end{array}$ & $\begin{array}{l}14 \\
44 \\
22 \\
20\end{array}$ & ns \\
\hline $\begin{array}{l}\text { Patients attitude } \\
\text { towards physical } \\
\text { exercises }\end{array}$ & $\begin{array}{l}\text { exercising unsystematically } \\
\text { not attaching a lot of weight to physical exercises } \\
\text { unexercising }\end{array}$ & $\begin{array}{l}11 \\
20 \\
19\end{array}$ & $\begin{array}{l}22 \\
40 \\
38\end{array}$ & $<0.05$ \\
\hline
\end{tabular}


Decreasing sex drive and deterioration of self-esteem were the main reasons for limitation or cessation of sexual contact by men and women. Sexual problems of women and men with stomas arose due to decreasing sexual activity most frequently. Most of the women and men did not achieve an orgasm. Above half of men (62\%) would not be ashamed of searching for help in order to resolve their sexual problems (Table 4).

\section{Intensity of emotions}

The most powerful intensity of emotion occurred among patients regarding acceptance of their fate, fear of death as well as happiness to be alive (above 4 points) (Fig. 1).

\section{Discussion}

Colorectal carcinoma is a significant social and oncological problem. More and more successfully cured people are also a challenge for rehabilitation staff. Patients with colorectal carcinoma after surgical treatment with creation of a stoma need special care because of closing of the natural way of defecation. Analysis of patients' statements about rehabilitation and its results as well as feelings regarding psycho-sexual issues was done by using the questionnaire.

In our study most of the patients came from big cities. It is confirmation that among men and women rectal carcinoma occurs among residents of cities more frequently than among residents of rural areas.

The patients' lifestyle changes radically after stoma creation in most cases. Patients do not return to preoperative activity in many fields of their life. In our study only a small percentage ( $6 \%$ ) of patients were still professionally active $(<0.05)$. However, in Szczepkowski's study [12] that percentage was significantly higher (40\%). The low percentage

Table 4. Psycho-sexual disturbances

\begin{tabular}{|c|c|c|c|c|}
\hline Item & & $N$ & $\%$ & $p$ \\
\hline $\begin{array}{l}\text { Persons from which } \\
\text { patients received } \\
\text { biggest psychic } \\
\text { support after } \\
\text { surgery }\end{array}$ & $\begin{array}{l}\text { physician } \\
\text { nurse } \\
\text { psychotherapist } \\
\text { physiotherapist } \\
\text { life partner } \\
\text { family } \\
\text { stoma's association } \\
\text { internet forum } \\
\text { persons manage problems themselves }\end{array}$ & $\begin{array}{r}38 \\
17 \\
6 \\
1 \\
22 \\
27 \\
7 \\
0 \\
6\end{array}$ & $\begin{array}{r}76 \\
34 \\
12 \\
2 \\
44 \\
54 \\
14 \\
0 \\
12\end{array}$ & $<0.05$ \\
\hline $\begin{array}{l}\text { Changes in } \\
\text { sexual life after } \\
\text { stoma }\end{array}$ & $\begin{array}{l}\text { unchanged } \\
\text { restriction of a sexual contacts } \\
\text { stopping of a sexual contacts }\end{array}$ & $\begin{array}{l}16 \\
16 \\
18\end{array}$ & $\begin{array}{l}32 \\
32 \\
36\end{array}$ & $<0.05$ \\
\hline $\begin{array}{l}\text { Using advices } \\
\text { from psychologist } \\
\text { or sexuologist }\end{array}$ & $\begin{array}{l}\text { yes it had an important influence on return to sexual life } \\
\text { yes but it had not an important influence on return to sexual life } \\
\text { not }\end{array}$ & $\begin{array}{r}2 \\
2 \\
46\end{array}$ & $\begin{array}{r}4 \\
4 \\
92\end{array}$ & ns \\
\hline $\begin{array}{l}\text { Reasons of restricted } \\
\text { or stopped sexual } \\
\text { relationships }\end{array}$ & $\begin{array}{l}\text { deteriorated selfassessment } \\
\text { fear of lack of acceptance from the partner side } \\
\text { shame } \\
\text { fear of smudging of dirt and unpleasure smell } \\
\text { decreasing of a sex drive } \\
\text { depressive mood }\end{array}$ & $\begin{array}{c}\text { Woman } \\
n / \% \\
11 / 55 \\
8 / 40 \\
3 / 15 \\
3 / 15 \\
14 / 70 \\
3 / 15\end{array}$ & $\begin{array}{c}\text { Man } \\
n / \% \\
5 / 16 \\
2 / 7 \\
3 / 11 \\
3 / 11 \\
28 / 95 \\
0\end{array}$ & $<0.05$ \\
\hline $\begin{array}{l}\text { Sexual problems } \\
\text { in women and } \\
\text { men with stoma }\end{array}$ & $\begin{array}{l}\text { decreasing in sexual activity } \\
\text { pain } \\
\text { vaginal dryness / erection disorders } \\
\text { problems with acheving an orgasm / malemissions }\end{array}$ & $\begin{array}{c}17 / 85 \\
2 / 10 \\
1 / 5 \\
0\end{array}$ & $\begin{array}{c}27 / 90 \\
0 \\
10 / 33 \\
8 / 26\end{array}$ & $<0.05$ \\
\hline $\begin{array}{l}\text { Frequency of } \\
\text { achieving an orgasm } \\
\text { in women and men } \\
\text { with stoma }\end{array}$ & $\begin{array}{l}\text { very often } \\
\text { often } \\
\text { rarely } \\
\text { never }\end{array}$ & $\begin{array}{c}0 \\
0 \\
9 / 45 \\
11 / 55\end{array}$ & $\begin{array}{c}3 / 10 \\
5 / 17 \\
10 / 33 \\
12 / 40\end{array}$ & $<0.05$ \\
\hline $\begin{array}{l}\text { Embarassment in } \\
\text { valuation of searching } \\
\text { for help in order to } \\
\text { resolve a sexual } \\
\text { problems }\end{array}$ & $\begin{array}{l}\text { yes } \\
\text { no } \\
\text { I do not know }\end{array}$ & $\begin{array}{r}N \\
13 \\
31 \\
6\end{array}$ & $\begin{array}{r}\% \\
26 \\
62 \\
12\end{array}$ & $<0.05$ \\
\hline $\begin{array}{l}\text { Influence of colostoma } \\
\text { on social relationships } \\
\text { and contact with family } \\
\text { and friends }\end{array}$ & $\begin{array}{l}\text { unchanged } \\
\text { changed towards more intensive } \\
\text { limiting to contacts with relatives } \\
\text { ceasing of social contacts }\end{array}$ & $\begin{array}{r}38 \\
2 \\
8 \\
2\end{array}$ & $\begin{array}{r}76 \\
4 \\
16 \\
4\end{array}$ & ns \\
\hline
\end{tabular}




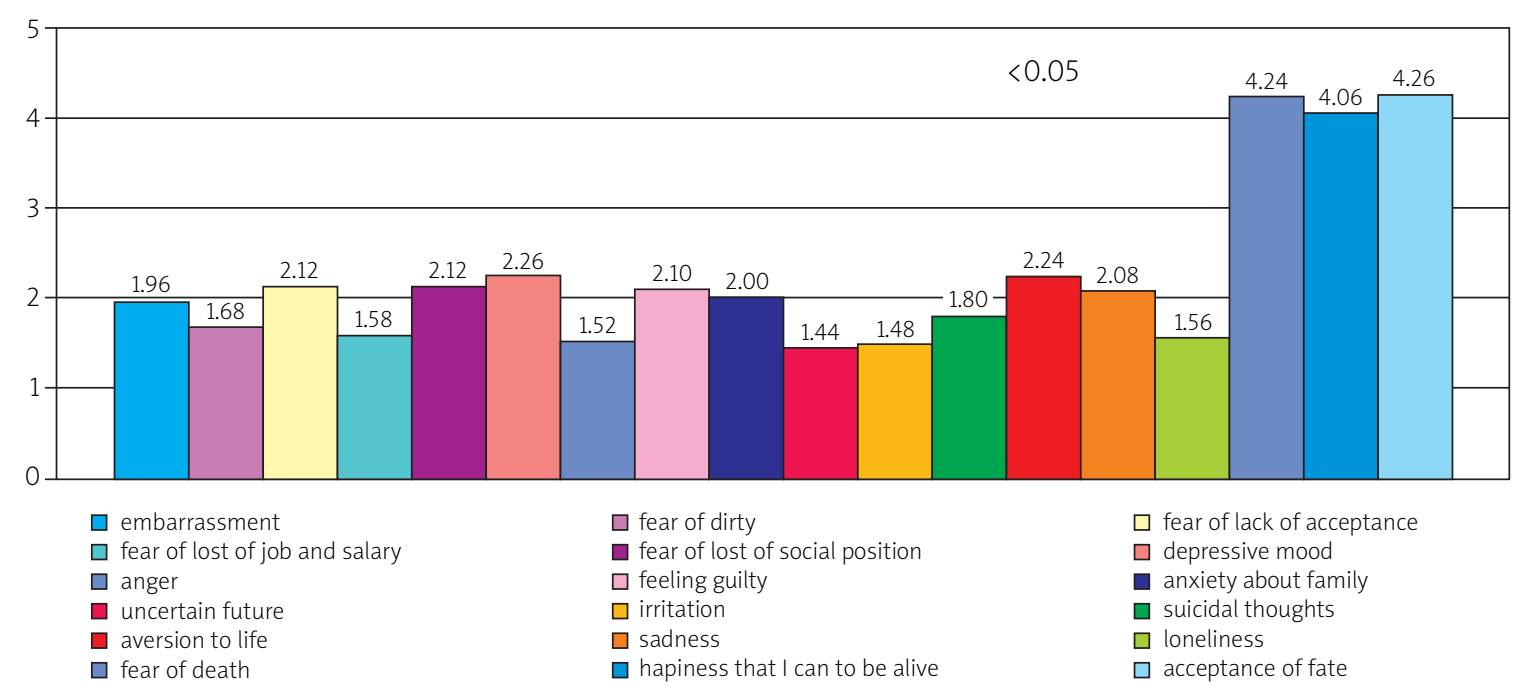

Intensity of feelings on five-point scale

Fig. 1. Intensity of feelings (medium)

in our study might arise from the fact that only half of our patients were professionally active before surgery. It seems that it is necessary to encourage patients more to continue their professional work or consider changing the type of work or its character in case of contraindications.

Economic conditions of surveyed patients before and after surgery did not change significantly, which is similar to results obtained in other studies that analyse the quality of life in patients with stoma [12].

Analysis of patients' family situation shows that only a few persons (6\%) were alone; the rest of patients live with their partners or families (84\%). However, other studies show that a greater number of patients lived alone [13]. The involvement of partners or families in the recovery process is important for complex rehabilitation and in consequence has an influence on improving the quality of life.

Most patients had a permanent stoma and only one fifth of them had a temporary stoma. It should be pointed out that continuity of the alimentary tract had not been restored in any cases. In patients who have undergone Hartman surgery it should be attempted to increase the frequency of restorative surgery, which could significantly improve the effectiveness of late rehabilitation and quality of life. In addition, the proper postoperative rehabilitation process should increase the percentage of restoration procedures in patients with stoma.

The scope of patients' knowledge about preoperative and early and late postoperative physical rehabilitation was analysed in detail. Among our surveyed patients only one third of them were familiarized with goals and above half of them had never heard about preoperative rehabilitation $(<0.05)$. In addition, the fact that also only one third of patients knew the goals of rehabilitation during the preand postoperative period is alarming $(<0.05)$. It shows that the importance of physical exercises before and after surgery is treated too superficially. It probably arises from insufficient education of medical staff about the role of phys- ical activity in the recovery process - medical staff pay too much attention to nursing factors. Lifestyle before surgery may have an effect on the degree of engagement in the process of rehabilitation after surgery. Persons leading a very active lifestyle before surgery stated that their physical activity was the same or slightly lower after surgery. Improvement in physical activity was declared by only a dozen or so patients and they are persons doing only basic physical activity. Most patients declared a decrease in their physical activity $(<0.05)$. They did only basic or minimal physical activity. It should be stressed that active lifestyle of patients with stoma is restricted significantly. The active lifestyle is maintained at the same level as before surgery only in those patients who were aware of the necessity of keeping active. Szczepkowski also showed that patients with stomas undertake active leisure rarely [12]. These results show insufficient knowledge and lack of information about the favourable effect of appropriate physical efforts on the recovery process. In our study only one tenth of patients noticed improvement in their physical and mental states after implementation of systematic physical exercises $(<0.05)$. The remaining patients did exercises unsystematically; they were not engaged in physical activity or did no exercises at all. Undoubtedly, it should be necessary to recommend physical exercises more often, and adjusting them to the patients' needs and possibilities is very important.

In current medicine, education plays an increasing role in prevention and treatment. Also, more and more patients show interest and intentions in increasing knowledge about their disease. Almost all patients (94\%) confirmed easy access to educational materials (brochures, leaflets, etc.) about stomas. Therefore it seems that accessibility of such materials is sufficient.

Most of the patients received information about skin care around the stoma, types of stoma devices, methods of replacement of stoma bags, and a slightly smaller number of patients about diet and reimbursement of stoma devices 
$(<0.05)$. This information is a basic knowledge set for patients with stomas. It is necessary for performing the appropriate rehabilitation process [9]. Only one third of patients received information about stoma services. Only a few of them got knowledge about psychological and sexual help and assistance. Only a dozen or so patients got knowledge about possibilities of the occurrence of complications in case of stoma. One tenth of patients received information about an Internet forum for stoma patients $(<0.05)$. These data show that it is necessary to pay more attention to the possibilities of using other knowledge resources (for instance, Internet portals, educational meetings) that deliver additional information about rehabilitation of patients with stomas.

The sexual life of patients after treatment of rectal carcinoma with stoma creation is a field of knowledge that has received little scientific examination. Many barriers exist regarding sexual life in this group of surveyed patients. In our study almost one third of patients stopped completely or limited their sexual relationships $(<0.05)$. Czernikiewicz [11] reported that as many as half of patients of both genders give up or limit their sexual life. Our study shows that decreasing sexual drive is the main reason for ceasing sexual relationships both in most women and almost all men $(<0.05)$. It agrees with studies performed by others [13-15]. Apart from that, lower self-esteem and fear (to a lower extent) of a lack of acceptance from the partner play an important role in ceasing sexual life in about half of women $(<0.05)$. Those problems concern men at a lower level. Similar results were obtained in other studies [11,14]. From the cultural point of view, outward appearance is more important for self-esteem for women than for men. A similar percentage for both genders was obtained regarding shame and fear of dirt and unpleasant smell as reasons for limitation of sexual relationships. Decrease of sexual activity concerns both women and men. Dyspareunia and pain during intercourse occurred most frequently in women, whereas erectile and ejaculation dysfunctions were most frequent in men.

Almost half of women and men with stomas reached an orgasm very rarely. The lack of achieving an orgasm was declared by over half of women and a small number of men $(p<0.05)$. In our study only two patients made use of a sexologist's advice when they wanted to return to sexual life. Frequent dysfunctions of sexual life in comparison with a small percentage of patients using professional advice should induce more frequent encouragement of patients to use sexual counselling, but a problem is the small number of professionals. Our research shows that the main reason for unsuccessful sexual rehabilitation is shame that occurs most frequently at the moment of starting searching for help in order to resolve sexual problems. Also Czernikiewicz [11] claims that patients do not admit to their sexual problems, are ashamed to talk about them, and patients with stomas visit a sexologist rarely.

The new situation in which patients with a stoma find themselves has a strong influence on their mental state [16]. Psychological support before and after surgery is a very important part of rehabilitation. In our study, patients after surgery received bigger psychological support from their physician than from their families, partners and nurses. Patients received support from a psychologist, stoma association and finally from a physical therapist at an insufficient level. Stronger influence and engagement of rehabilitation staff regarding the patient's psychological state would be greatly appreciated. It seems that easier access to a psychologist could bring significant improvement in mental rehabilitation.

Social relationships and relations with close relatives did change significantly in most of the surveyed patients. Only a few of them limited their social relationships to the form of relations with close relatives and several persons gave up their social life. A positive attitude toward persons with a stoma and maintenance of social relationships have an important influence on faster return to social activity [14].

Additionally, feelings and emotions of patients with a stoma that have a significant influence on their psychological rehabilitation were analysed in this work. The intensity of each feeling has been shown using a 5-point scale. Patients felt shame, fear of dirt, lack of acceptance, fear of loss of their job and earnings, uncertainty of the future, irritation and loneliness only to a small degree. Slightly more patients felt anger, sense of guilt, fear of family, fear of loss of social position, depression, loss of the will to live and sadness. Accepting their fate, fear of death and happiness that they could be alive were feelings with the strongest intensity among patients $(<0.05)$.

Our own research is confirmed by other publications stating that patients with stomas have many psychological problems requiring help from the rehabilitation team for their resolution, especially obtained from a psychologist and/or psychiatrist [14-16]. Although psychological rehabilitation may have great importance for patients with a stoma, physical and sexual rehabilitation should not be omitted. Only implementation of all three elements of rehabilitation may have the greatest influence on the patient's wellbeing and improvement of his/her quality of life.

\section{Conclusions}

1. Participation in physical rehabilitation during the perioperative period in the treatment of patients who suffered from colorectal carcinoma with a stoma was insufficient.

2. The psycho-sexual part of rehabilitation, which has been used by only a few patients, was the most neglected element of the rehabilitation process.

3. Accepting their fate, fear of death and happiness that they could be alive were the feelings with the strongest intensity.

\section{References}

1. Olędzki J. Własna modyfikacja zbiornika jelitowego jako metody rekonstrukcji jelita grubego po resekcji raka odbytnicy. Nowotwory 2003; 53: 9-23.

2. Banaszkiewicz Z, Jarmocik P, Jawień A. Stomie jelitowe - przyczyny i zasady wyłaniania. Valetudinaria 2004; 9: 106-9.

3. Kołodziejczak M. Opieka nad pacjentem ze stomią. Med Rodz 2006; 4: 3-8.

4. Tchórzewska H. Rehabilitacja pacjentów z wyłonioną stomią. Convatec, Warszawa 2006. 
5. Turnbull GB. Is there a gap in ostomy rehabilitation? Ost Wound Man 2006; 50: 78-85.

6. Erwin PT. Ostomy care and rehabilitation in colorectal cancer. Semin Oncol Nurs 2006; 22: 174-7.

7. Szumska A, Cierzniakowska K, Szewczyk M, Stodolska A, Banaszkiewicz Z, Jawień A. Sposoby zaopatrzenia pacjentów ze stomią jelitową. Valetudinaria 2004; 9: 10-113.

8. Rayson E. Living well with an ostomy. Your Heath Press, Canada 2003.

9. Cwajda J, Idczak H, Szewczyk M, Banaszkiewicz Z, Cierzniakowska K, Jawień A. Potrzeby i oczekiwania edukacyjne pacjentów z kolostomia. Valetudinaria, 2004; 9: 114-9.

10. Borwell B. The psychosexual needs of a stome patients. Prof Nurs 1997; 12: 39-46.

11. Czernikiewicz W. Życie seksualne pacjentów ze stomią. Troska 2002; 3: 9-10.

12. Szczepkowski M. Rak odbytnicy czynnościowe wyniki leczenia i jakość życia. Proktologia 2003; 2: 27-40.

13. Cierzniakowska K, Szewczyk TM, Stodolska A, Cwajda J, Banaszkiewicz Z, Jawień A. Proces rehabilitacji chorych ze stomią. Nowiny Lekarskie 2005; 74: 22-25

14. Gooszen AW, Geelkerken RH, Hermans J, Lagaay MB, Gooszen HG. Quality of life with a temporary stoma: ileostomy vs coloctomy. Dis Colon Rectum 2000; 43: 650-655.

15. Deeny P, McCrea H. Stoma care: the patients perspective. J Adv Nurs 1991; 16: 39-46

16. Wrońska I. Jakość życia chorych z rakiem jelita grubego i wytworzonym brzusznym odbytem. Psychoonkologia 2003; 7: 37-42.

\section{Address for correspondence}

Andrzej Nowicki MD, PhD, Prof. UMK

Techników 3

85-801 Bydgoszcz

tel. 602383210

e-mail: anow1_xl@wp.pl 